NBSIR 83-2798

\title{
Multi-Year Affirmative Action Program for Women and Minorities for Fiscal Years 1982 Through 1986 Washington, DC, and Boulder, CO
}

EXECUTIVE SUMMARY

U.S. DEPARTMENT OF COMMERCE

National Bureau of Standards

Office of the Director of Administration

Equal Employment Opportunity

Support Division

Washington, DC 20234

October 1983

Issued December 1983
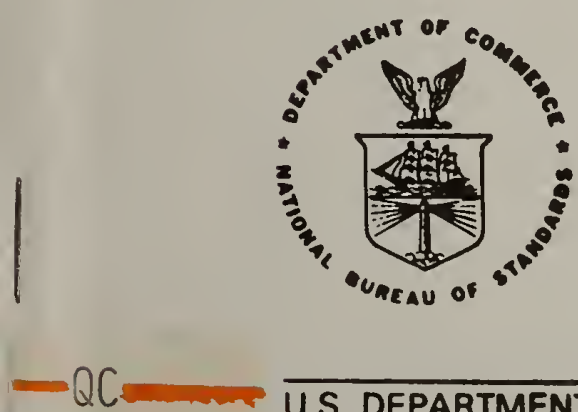

U.S. DEPARTMENT OF COMMERCE 

NBSIR 83-2798

MULTI-YEAR AFFIRMATIVE ACTION

PROGRAM FOR WOMEN AND

MINORITIES FOR FISCAL YEARS 1982

THROUGH 1986 WASHINGTON, DC

AND BOULDER, CO

EXECUTIVE SUMMARY

Linda K. Despeaux

U.S. DEPARTMENT OF COMMERCE

National Bureau of Standards

Office of the Director of Administration

Equal Employment Opportunity

Support Division

Washington, DC 20234

October 1983

Issued December 1983

U.S. DEPARTMENT OF COMMERCE, Malcolm Baldrige, Secretary NATIONAL BUREAU OF STANDARDS, Ernest Ambler, Director 

The purpose of this report is to provide a summary of NBS' Affirmative Action Program for Women and Minorities for use by NBS managers who have responsibility for its implementation. If you are interested in reviewing the full version of the Multi-Year Affirmative Action Program Plan (MYAAPP), copies are available in the headquarters office of each of our major operation units, the Personnel Division, the Library, and the EEO Support Division. In Boulder, copies are available in the office of the Director and in the office of the EEO Coordinator. 
Foreword ........................ 1

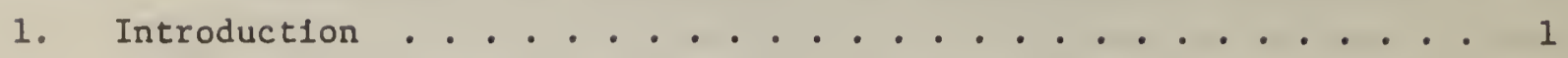

2. Work Force Analysis ................ 2

3. Labor Market Avallabllity . . . . . . . . . . . 5

4. Hiring Goals .................. 10

5. Barriers to Improving the Representation of Women and Minorities in the Work Force ............ 13

6. Federal Equal Opportunity Recru1tment Program . . . . . . . 16

7. Program Evaluation ................. 22 


\section{INTRODUCTION}

Requirements for the establishment of Federal agency affirmative action programs were first cited by Executive Order 11478 in 1969. Title VII of the Civil Rights Act, as amended in 1972, mandated Federal agencies to maintain affirmative action programs to ensure enforcement of equal employment policy. Early affirmative action programs were often disappointing because the Federal sector's approach to affirmative action relied heavily on the achievement of numerical employment goals. In addition, we attempted to apply short-range solutions (the annual affirmative action plan) to long-range problems (decades of discrimination). One obvious alternative to this short-range approach is "multi-year" affirmative action planning, which has the advantage of applying longrange solutions to difficult problems in a rational and systematic manner. The multi-year plan allows the orderly integration of affirmative employment activities; provides time for experimenting with different strategies; and allows flexibility for shifting resources and goals to accommodate changes in the agency's staffing needs, programs, and fiscal allocations.

The NBS multi-year affirmative action program has been designed to assist the Bureau in meeting the goal established by Congress in the Civil Service Reform Act of 1978--i.e., "to provide...a federal workforce reflective of the nation's diversity...." The plan was developed by using a systematic approach to affirmative action planning and program development which included (1) performing a comprehensive analysis of our work force to determine occupations and grade levels in which women and minorities are underrepresented, (2) analyzing barriers which have prevented us from achieving a representative work force in the past, and (3) identifying strategies which can be used to improve the distribution and quantity of women and minorities in our work force.

The multi-year program was developed to accommodate two conditions. First NBS does not anticipate significant expansions in budget or personnel ceilings during the next several fiscal years. Second, the labor market has a limited quantity of women and minority candidates available for employment in scientific and engineering occupations. Because NBS feels it has a commitment to pursue affirmative action activities which are consistent with these conditions, our primary focus is on:

- Expanding our outreach efforts with organizations which can impact on the quantity and quality of women and minorities entering occupations in which NBS has staffing requirements.

- Increasing the use of internal mechanisms such as training, formal staffing programs, and developmental assignments to move employees into a wider range of occupations and into higher graded positions.

- Establishing hiring goals which are consistent with labor market participation of women and minorities. 
The Equal Employment Opportunity Commission (EEOC) has suggested that an appropriate goal for the Federal Government is that our permanent work force be reflective of the civilian work force. The basis of NBS' multi-year program plan was a comprehensive work force analysis to determine the degree to which women and minoritles are underrepresented by comparing the percentage of employees in each minority/sex group in our major occupations with the percentage of those same sex/minority groups in the civillan labor force. The 1981 EEOC Guidelines for Development of Multi-Year Affirmative Action Programs state that agencles can compare themselves to either local or national data if they can demonstrate that their recruitment and hiring is done from that area. NBS has, therefore, chosen to use national professional civilian labor force data for determining underrepresentation in professional occupations and approprlate local data for determining underrepresentation of non-professional occupations in Galthersburg and Boulder.

Analysis of the NBS professional work force revealed the following areas of underrepresentation.

\begin{tabular}{|c|c|c|}
\hline Occupation & $\begin{array}{l}\text { Underrepresented } \\
\text { Group }\end{array}$ & \\
\hline Engineer & $\begin{array}{l}\text { Non-Minority } \\
\text { Black } \\
\text { Hispanic } \\
\text { Asian } \\
\text { American Indian }\end{array}$ & $\begin{array}{l}F \\
M, F \\
M, F \\
F \\
M, F\end{array}$ \\
\hline $\begin{array}{l}\text { General Physical } \\
\text { Sclentist }\end{array}$ & $\begin{array}{l}\text { Non-Minority } \\
\text { Black } \\
\text { Hispanic } \\
\text { Asian } \\
\text { American Indian }\end{array}$ & $\begin{array}{l}F \\
F \\
M, F \\
M, F \\
M, F\end{array}$ \\
\hline Physicist & $\begin{array}{l}\text { Non-Minority } \\
\text { Black } \\
\text { Hispanic } \\
\text { Asian } \\
\text { American Indian }\end{array}$ & $\begin{array}{l}F \\
M, F \\
M, F \\
F \\
M, F\end{array}$ \\
\hline Chemists & $\begin{array}{l}\text { Non-Minority } \\
\text { Black } \\
\text { Hispanic } \\
\text { Asian } \\
\text { American Indian }\end{array}$ & $\begin{array}{l}F \\
F \\
M, F \\
F \\
M, F\end{array}$ \\
\hline $\begin{array}{l}\text { Math/Computer } \\
\text { Science }\end{array}$ & $\begin{array}{l}\text { Black } \\
\text { Hispanic } \\
\text { American Indian }\end{array}$ & $\begin{array}{l}M, F \\
M, F \\
F\end{array}$ \\
\hline
\end{tabular}

${ }^{1}$ As of $7 / 83$. 
Analysis of the non-professional staff, which compared the distribution of women and minorities to local civilian work force data, revealed the following:

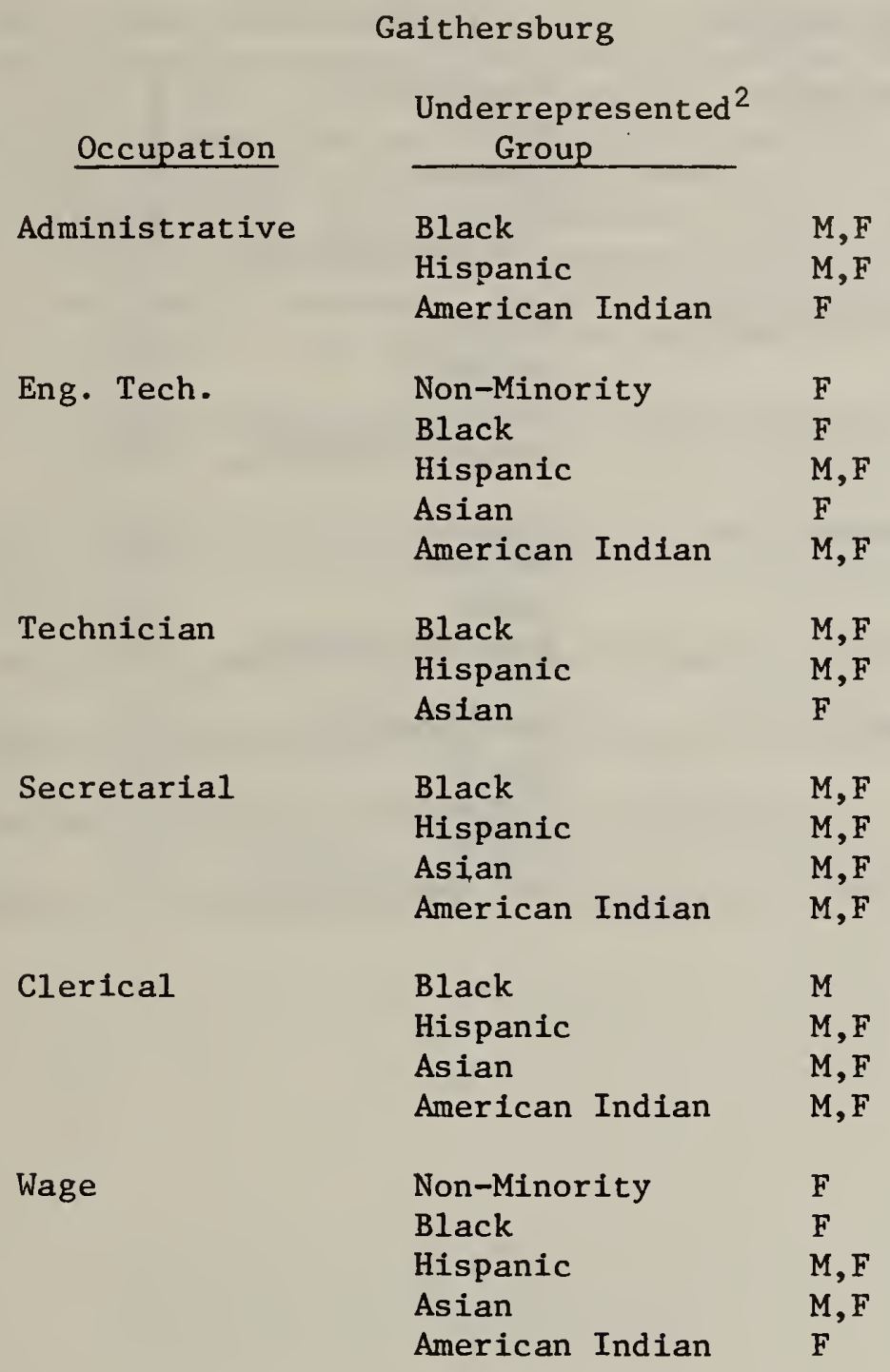




\begin{tabular}{|c|c|}
\hline Occupation & $\begin{array}{l}\text { Boulder } \\
\text { Underrepresented }^{3} \\
\quad \text { Group } \\
\end{array}$ \\
\hline Technician & $\begin{array}{l}\text { Non-Minority } \\
\text { Black } \\
\text { Hispanic } \\
\text { Asian } \\
\text { American Indian }\end{array}$ \\
\hline Administration & $\begin{array}{l}\text { Black } \\
\text { Hispanic } \\
\text { Asian } \\
\text { American Indian }\end{array}$ \\
\hline Clerical & $\begin{array}{l}\text { Black } \\
\text { Hispanic } \\
\text { Asian } \\
\text { American Indian }\end{array}$ \\
\hline Wage & $\begin{array}{l}\text { Non-Minority } \\
\text { Black } \\
\text { Hispanic } \\
\text { Asian } \\
\text { American Indian }\end{array}$ \\
\hline
\end{tabular}


In order to determine the degree to which underrepresentation can be corrected through changes in hiring patterns, It was essential to assess the current labor market avallability of women and minorities in the scientific and engineering labor market. With that in mind, a second work force analysis was done to compare the distribution of women and minorities in each of our major scientific occupations with the distribution of those groups in the Federal Government and in the civilian work force. For example, the distribution of engineers at NBS was compared with the distribution of engineers in the Federal Government and the distribution of engineers in the civilian work force. (See Tables 1 through 4.)

Analysis of the data showed that the following groups are underrepresented when we compare NBS with the civilian work force data for each occupation:

- Non-minority females are underrepresented at NBS in Engineering, Physics, and Chemistry.

- Black males are underrepresented in Math/Computer Sciences.

- Black females are underrepresented In Physics and Math/Computer Sclences.

o Hispanic males are underrepresented in Engineering.

o Asian females are underrepresented in Physics and Chemistry. 
s.

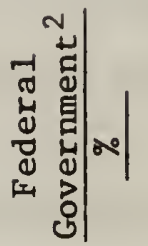

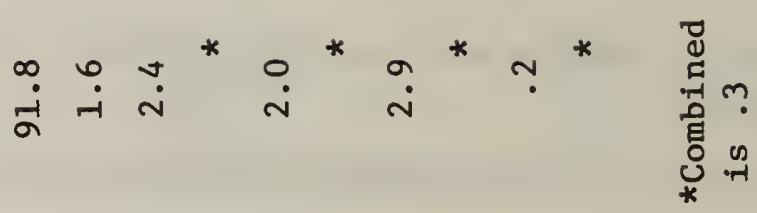

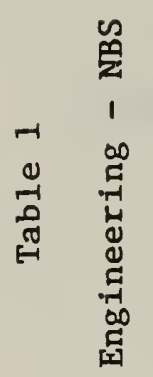

๑|

战|

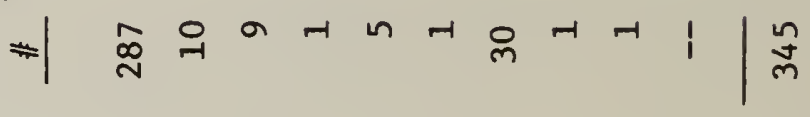

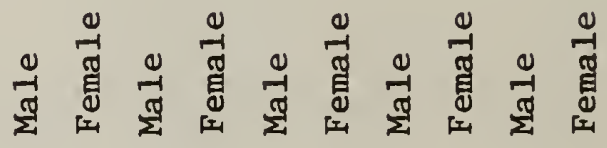

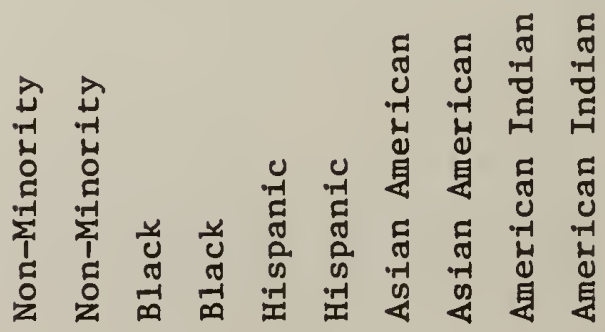

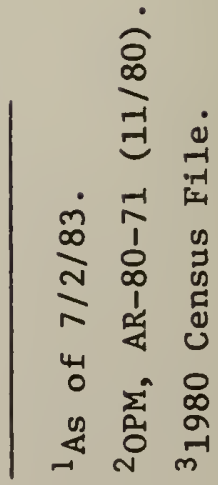




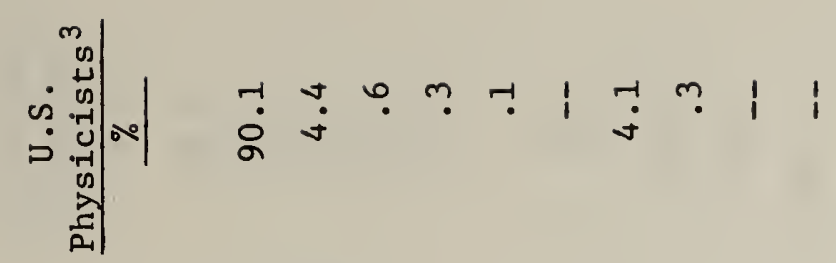

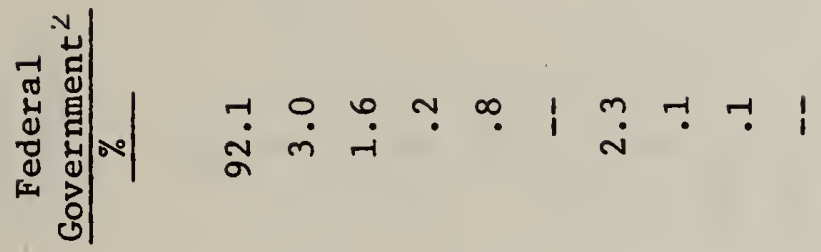

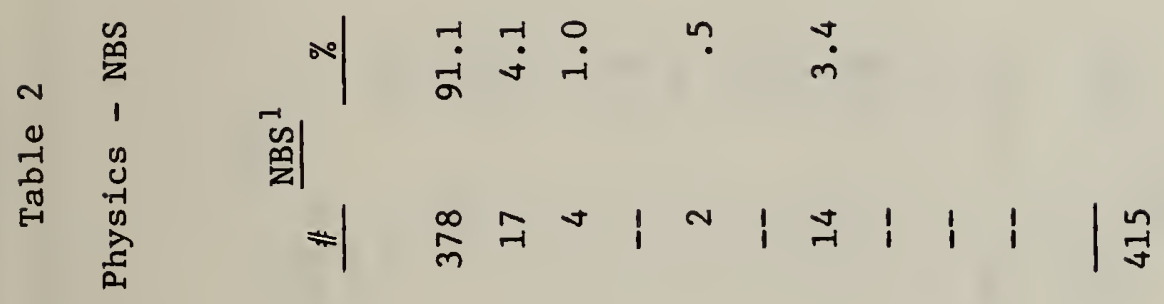

变

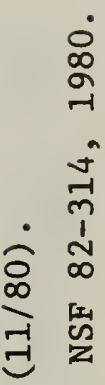

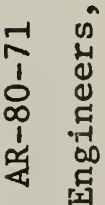

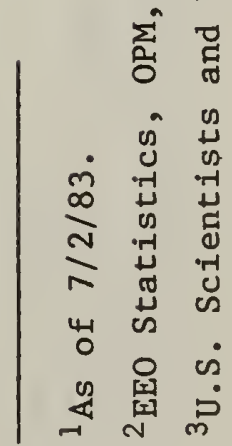

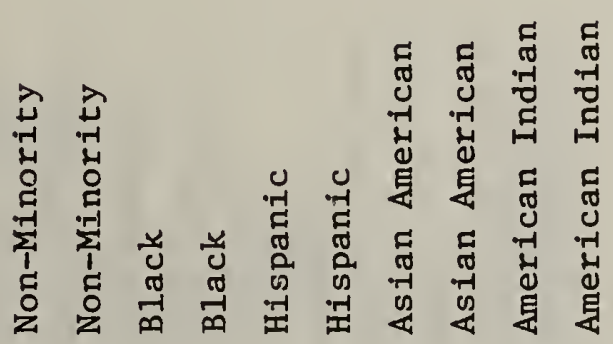




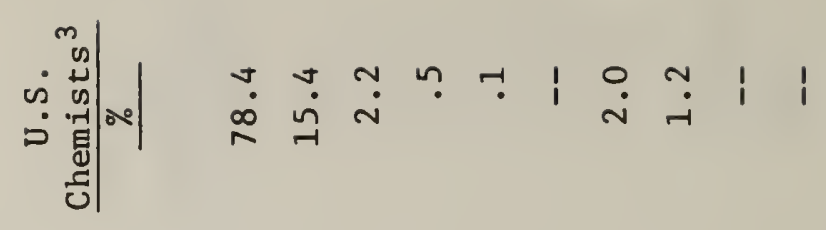

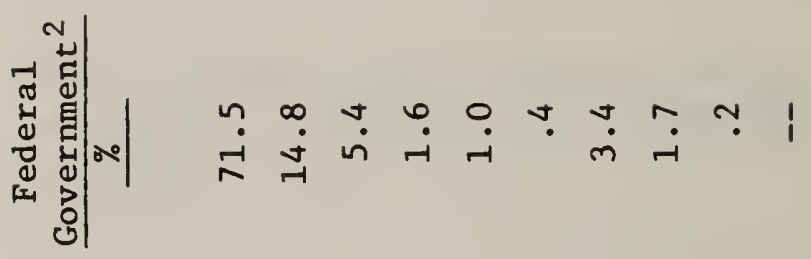

m

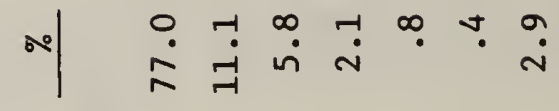

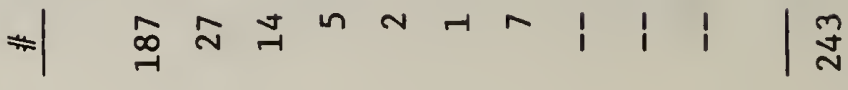

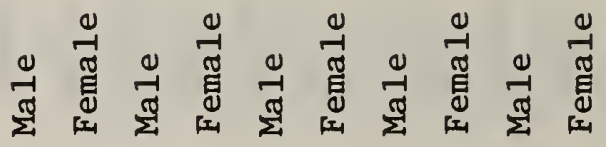

品 


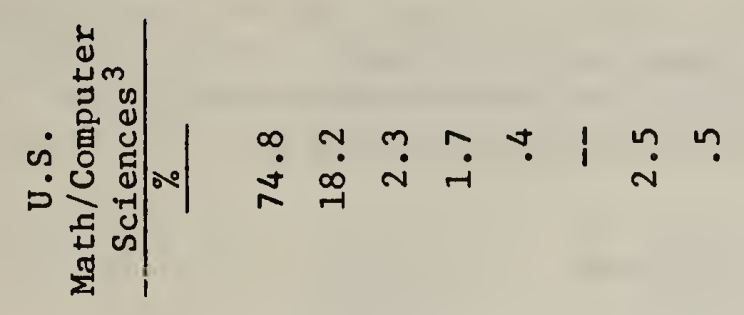

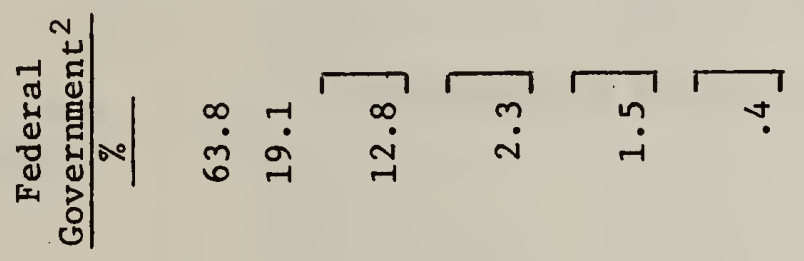

$\stackrel{2}{2}$

ง

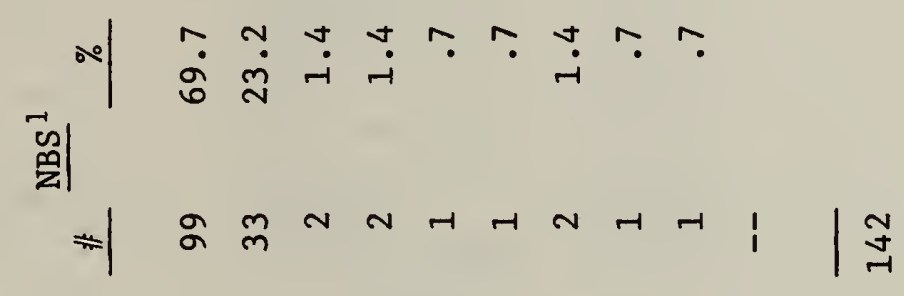

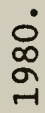

苟

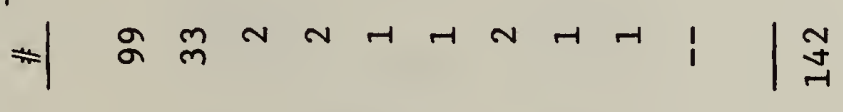$$
\text { 变 }
$$

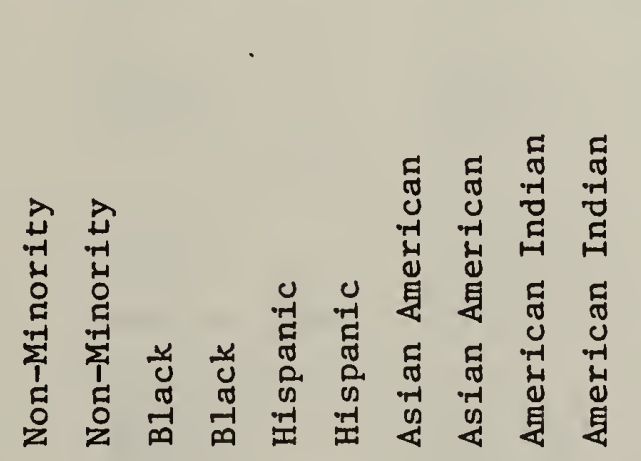




\section{HIRING GOALS}

Hiring goals are established annually by each of NBS' major operating units. These goals represent a reasonable estimate of the portion of total hires which can be expected to come from underrepresented groups. During the goal setting process each MOU Director considers the following key factors:

1. Total number of new hires expected.

2. Size of the labor market for women and minorities.

3. NBS' ability to compete with private and Federal organizations seeking the same candidates.

Tables 5 and 6 represent the FY 84 hiring goals. 
Table 5

FY 84 H1ring Goals

NBS Galthersburg

Targeted

Underrepresented NBS

Occupation Group

Goal

\section{Engineering}

Non-Minority

Black

Hispanic

Asian

American Indian

General Physical

Sclentist

\section{Non-Minority}

Black

Hispanic

Asian

American Indian

Physicist

Non-Minority

Black

Hispantc

Asian

American Indian

Chemists

Non-Minority

Black

Hispanic

Asian

American Indian

Math/Computer

Science

Black

Hispanic

American Indian

Misc. Prof.

Administrative

Black

American Indian

Black

Hispanic

American Indian

Eng. Tech.

Non-Minority

Black

Hispanic

Asian

American Indian

Technician

Black

Hispanic

Asian

Secretarial

Clerical

Wage

Black

Hispanic

Asian

American Indian

Black

Hispanic

Asian

American Indian

Non-Minor1ty

Black

Hispanic

Asian

American Indian

Other

Non-Minority

Black

Hispanic

Asian.

American Indian

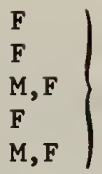

2

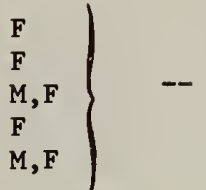

$\mathrm{M}, \mathrm{F} \quad 2$

F

$\mathrm{M}, \mathrm{F}$

$F$
$F$
$M, F$
$F$
$M, F$

$\left.\begin{array}{l}\mathrm{M}, \mathrm{F} \\ \mathrm{M}, \mathrm{F}\end{array}\right\} \quad 3$

F

$\left.\begin{array}{l}M, F \\ M, F\end{array}\right\}$

2

$\left.\begin{array}{l}M, F \\ M, F \\ F\end{array}\right\}$

6

$F$
$F$
$M, F$
$F$
$M, F$

$\left.\begin{array}{l}M, F \\ M, F\end{array}\right\} \quad 8$

$\mathrm{M}, \mathrm{F}$

$\mathrm{M}, \mathrm{F}$

$\mathrm{M}, \mathrm{F}$

M

M,F

$M, F$

$\mathrm{M}, \mathrm{F}$

F

F

M, F

$\mathrm{M}, \mathrm{F}$

1

\begin{tabular}{l|l} 
F \\
F \\
M,F \\
M,F
\end{tabular} \mid $\begin{aligned} & \\
& \end{aligned}$ 
Table 6

FY 84 Hiring Goals NBS Boulder

Occupation

Professional

Administration

Technician

Clerical

Wage

Other
Targeted

Underrepresented

Group

NBS

Goal

Non-Minority

Black

Hispanic

Astan

Amer. Indian

Black

Hispanic

Asian

Amer. Indian

Non-Minority

Black

Hispanic

Amer. Indian

Black

Hispanic

Asian

Amer. Indian

Non-Minority

Black

Hispanic

Non-Minority

Black

Asian

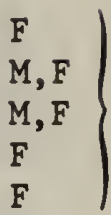

5

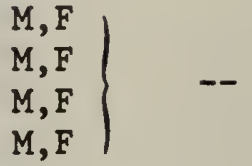

$\begin{aligned} & F \\ & F \\ & M \\ & M, F\end{aligned} \mid 2$

\begin{tabular}{l|l}
$M, F$ & \\
$M$ & 1
\end{tabular}

$M, F$

$\mathrm{M}, \mathrm{F}$

$\left.\begin{array}{l}F \\ M, F\end{array}\right\}$

3

$\left.\begin{array}{l}F \\ F \\ M, F\end{array}\right\} \quad 2$

13 
BARRIERS TO IMPROVING THE REPRESENTATION OF WOMEN AND MINORITIES IN THE WORK FORCE

In order for the Federal Government to improve the distribution and representation of women and minorities in its work force, it is important for all agencies to implement activities which lead to removal of barriers which have historically prevented us from locating, recruiting, employing, or developing women and minorities. During FY 82 the EEO Division and representatives from Personnel, the major operating units, and various employee groups did an analysis of barriers affecting NBS. Following are the barriers which the NBS Executive Board targeted for action during FY 83 and FY 84 and a description of actions which have been taken to date as remedies for removal or alleviation of the problem:

Barrier. The labor market availability of women and minorities in the scientific and engineering work force is limited.

One approach to alleviating this problem is for NBS to expand its outreach activities with organizations and educational institutions which have an impact on the quantity and quality of women and minorities choosing careers in science and engineering. NBS' outreach activities are designed to increase the labor market availability of women and minorities in occupations in which their availability is limited. Examples of current outreach activities are:

\section{Community Education Program (CEP)}

This program was created by NBS during FY 82 as one means for providing female, minority, and handicapped students in Montgomery County with the experience needed to make informed choices about careers in science. During FY 83, the program was expanded into the District of Columbia and Howard County to reach more schools with large minority populations. As part of the program, NBS scientists make presentations to junior and senior high students on scientific topics usually related to the work they do at NBS. At present we have approximately 13 NBS staff members in the CEP Speakers Bureau. In addition, high school students are provided opportunities for a summer of volunteer work experience in an NBS laboratory. Shorter term appointments are also available for students who have made a preliminary choice to pursue a career in science. Students who are given Shadow appointments spend from one-half to two days with a professional to observe day-to-day scientific activities.

\section{Support to Historically Black Colleges}

Executive Order 12320 directed Federal agencies to develop a Plan for Support to Historically Black Colleges (HBCs). NBS' FY 84 plan calls for a percentage of expenditures for HBCs and describes activities which are expected to increase working relationships between NBS and HBCs. NBS support to black colleges to date has included: 

spent at educational institutions.

- A file describing the technical competencies of HBCs has been developed for use by NBS managers in their grants giving and contracting activities.

- NBS and the Association for the Advancemert of Black Scientists and Engineers have held two one-week workshops on the "State-of-the-Art in Analytical Chemistry." The objectives of the workshops were 1) to provide faculty members and high-potential students from HBCs with theoretical and practical exposure to state-of-the-art instrumental methods for chemical analysis and 2) to establish a rapport between NBS, the particlpating institutions, faculty members, and students. Over fifty members and students attended each workshop which included technical presentations and tours of the facilities.

- NBS' National Englneering Laboratory held a three-day orientation and training seminar on "Computing at NBS." The primary purpose of the seminar was to acquaint faculty at HBCs with NBS and the variety of career opportunities that it has to offer their graduates. Over twenty faculty members attended the seminar which included technical presentations and tours to give them impressions of the facilities and the type of work done at NBS.

Barrier. Funding and slot reductions have resulted in decreases in a number of formal programs which provided opportunities for the career mobility of current employees.

During FY 83, the following activities were inftlated to help create more in-house activities:

1. The Personnel Division wrote a memorandum to all NBS supervisors explaining upward mobility and encouraging them to use this type of appointment as an alternative to recruitment from outside for many paraprofessional and technical positions.

2. A FY 84 budget initlative has been submitted for an Administrative Intern Program. It is hoped that through such a program minority participants can be developed.for administrative positions such as budget analysts and personnel specialists.

Barrier. Our traditional approach to recruitment for mid-level positions has not reached many women or minority candidates. Overall, our knowledge about the most effective strategles for reaching women and minority engineers and scientists is limited.

The following activities have been initiated to help us increase our knowledge of viable recruitment technique and to attract a greater number of minority candidates.

1. The MOU EEO Coordinators have redesigned the Affirmative Action Recruitment Report (NBS-1116) so that 1t can be used to document all stages in affirmative recruitment progress. The new design 
will permit the MOU EEO Coordinator to review recruitment plans prior to posting of vacancies and to assist selection officials to develop strategies for attracting minority and female candidates.

2. During FY 83 working relationships have been developed with the following organizations:

- FEORP Clearinghouse--The Clearinghouse was established to serve as a forum for Federal representatives for sharing information on techniques and programs for locating, recruiting, and developing women and minorities. An EEO Division staff member has joined the group and w111 be serving on the Clearinghouse Subcommittee for Advancement of Engineering, Technological and Scientific Careers.

- NBS' technical staff members have reported that this year to date they have contacted and are working with professional associations such as Association for Women in Computing, Society of Women in Engineering, Association for Women in Science, National Association of Black Chemists and Chemical Engineers, and National Black Physicists Association

It is hoped that these sources will expand our recruitment network, help us to develop new recruitment techniques, and lead to additional candidates for employment. 


\section{Background}

Section 310 of the Civil Service Reform Act of 1978 mandated the establishment of a minority recrultment program almed at improving the representation of minorities in various categorles of civil service employment. It defined underrepresentation as a situation in which the percentage of members of a minority group within an employment category is lower than the percentage of that minority group within the civilian labor force of the United States. In December 1978, EEOC published in the Federal Register its "Guidelines for the Development of a Federal Recruitment Program to Implement 5 U.S.C. Section 7201." Those guidelines defined the following as minority groups: Black, Hispanic, American Indian/Alaskan Native, and Asian American/Pacific Islander. (They also interpreted the statute to include both minority and non-minority women within the scope of the program.) The guldelines included the following provistons which represent what individual agency programs should accomplish:

1. The program design should result in applicant pools with sufficient members of underrepresented groups.

2. The program should strive to stimulate the interest of underrepresented groups in occupations where there are realistic projections of Federal employment opportunities.

3. The program should be based on determinations of underrepresentation in the agency's total work force and should be made by grade level and by broad occupational, professlonal, and other groupings as determined by OPM.

4. The program should use local civilian labor force data in making determinations of underrepresentation if that local percentage for a particular minority group is higher than the group's representation in the national civilian labor force. This effectively required agency components located in areas with high minority concentrations to assume a larger share of the burden of eliminating underrepresentation than others. 1

5. The program should interpret recruitment to include internal as well as external activitles.

${ }^{2}$ The 1981 EEOC guidelines for development of Mult1-Year Affirmative Action Programs state that agencies can use state or national data if they can demonstrate that their recruitment and hiring is done from that area. NBS has, therefore, chosen to use national professional civilian labor force data for determining underrepresentation in professional occupations and Washington civilian labor data for non-professional occupations. 
6. The program should gather data on the applicant pools by race, national origin, and sex.

Although the program's primary objective is to recruit minorities for Federal employment, a personnel management function, it overlapped with affirmative action and EEO program objectives, an enforcement responsibility of the EEOC. Therefore, the EEOC guidelines call for the minority recruitment program to be incorporated as an element of agency affirmative action plans.

FY 84 FEORP Plan

The following sections describe the FEORP strategies that will be used in FY 84 to increase the representation and improve grade spread of women and minorities in these occupations.

\section{$\underline{\text { Training Program }}$}

NBS encourages and supports a myriad of training and developmental experiences for its employees. This emphasis on training serves the Bureau by (1) increasing the skills, knowledges, and abilities of employees; (2) improving present job performance; (3) developing "state-of-the-art" knowledge; and (4) preparing for anticipated changes in mission, function, equipment, or personnel. Through the use of this FEORP mechanism, women and minorities become better prepared to move into other occupations and to assume positions of greater responsibility.

The following specialized training programs will be conducted during FY 84 to develop current employees:

- Graduate Research Fellowship Program--An academic research study program primarily for current employees who are pursuing graduate study in a field of interest to NBS. It involves a minimum of one year of formal study/research support with an agreement to remain at NBS for three times the length of the education program. In addition, the employees receive full salary plus all education/researchrelated expenses.

- Administrative Intern Program--A FY 84 budget initiative has been submitted to fund this program to develop minorities for Administrative Professional positions at NBS. The program will develop in-house candidates by providing (1) rotational assignments to key administrative areas at NBS, (2) skills training at local community colleges, (3) OPM training on government administrative operations, and (4) seminars sponsored by individual administrative officers. craft/trade occupations such as carpenter, painter, air conditioning mechanic, and sheet metal worker. 


\section{Formal Recruitment Programs}

The following "plpeline" programs will be used to provide prospective candidates for professional positions.

- Technical Recruitment Program--Primary responsibility for recruitment of entry-level technical staff resides with the technical managers. In this capacity, they develop a working relationship with the faculty and get to know college students early in their college careers. These contacts generally lead to identification of women and minority students for the Cooperative Education Program and for summer employment.

- Summer Employment Program--This program gives college faculty and students an opportunity to do research work and to become better acquainted with programs at NBS.

- Federal Junior Fellowship Program--This program provides continuing summer and vacation employment, until college graduation, for outstanding high school senfors who plan to attend college and who have expressed an interest in a career in the Federal service. Participants are eligible for non-competitive conversion to a career-conditional (permanent) appointment in the agency upon completion of degree requirements.

- Graduate Cooperative Education Program--The program for graduate students is designed to provide rotating assignments of work with rotating assignments of study. Appointments are made under a written agreement with the student's college. Upon graduation, the student is eligible for non-competitive converston to careerconditional appointment.

\section{Personnel Management Techniques}

A number of supportive personnel management techniques are used which often lead to identification of positions which can provide advancement opportunities for women and minorities. For example:

- Review of Vacancies--NBS managers review newly created positions and vacancles in order to identify opportunitles for restructuring positions, distributing duties to current staff members to provide advanced career potential, and creating formal upward mobility positions.

- Analysis of Merit Certificates--Because of the high percentage of employment opportunities which are filled without the benefit of minority or female applicants, the directors of each major operating unit personally review merit certificates which lack minority or female candidates to determine whether the position should be readvertised for additional candidates.

NBS will use the following special staffing techniques to find and attract a greater number of women and minority applicants for employment: 
Affirmative Action Recruitment Report--This report, which accompanies all vacancy announcements, has recently been implemented as a mechanism for documenting all stages of recruitment. The report will permit EEO Coordinators from each of NBS' major operating units to review plans prior to posting of vacancies and to assist selecting officials to develop strategies for attracting minority and female candidates.

- Attendance and Participation at Conferences--NBS technical staff members attempt to locate applicants when they attend technical conferences and professional association meetings.

\section{Interaction with Women's and Minority Organizations}

NBS interacts with external organizations to publicize the work of NBS and to use the services of those organizations in locating women and minority applicants. During this fiscal year, NBS staff members will. expand working relationships with:

- Atlanta University Center Dual Degree Program--The Dual Degree Program joins the resources of the Atlanta University Center (AUC) with those of engineering programs at Georgia Institute of Technology, Boston University, Auburn University, and Rochester Institute of Technology. Under the Dual Degree Program, a student attends one of the undergraduate colleges of the AUC for approximately three years and an additional two years at one of the engineering institutes. Upon successfully completing the program, the students will simultaneously receive two deOrees--a bachelor of arts or a bachelor of science degree awarded by the AUC college attended and a designated bachelor of engineering degree from the engineering institution.

- FEORP Clearinghouse--The Clearinghouse was established to serve as a form for Federal representatives for sharing information on techniques and programs for locating, recruiting, and developing women and minorities. An EEO Division staff member has joined the group and will be serving on the Clearinghouse Subcomittee for Advancement of Engineering, Technological and Scientific Careers.

- Research Fellowship--The National Engineering Laboratory (NEL) has established a Resident Research Fellowship for a faculty member from a Historically Black or predominantly women's college. The fellow will work at NBS for up to one year on independent research or in collaboration with scientists and engineers in NEL. NBS

hopes that such a program will lead to future cooperation between NBS and the fellow's college or university.

\section{Outreach Efforts to Increase Applicant Pool}

Because of the highly technical nature of many of our FEORP occupations-physical scientists, chemists, and engineers--there are a limited number of candidates actually in the pipeline for employment in the next two to five years. NBS recognizes it has a responsibility to develop mechanisms for interacting with schools to encourage women and minorities to enter 
into occupations which are of interest to NBS. The following programs are used with the hope of increasing the future applicant supply.

- Student Volunteer Program--The program provides opportunities for students to participate in career exploration by establishing educationally-related work assignments in a nonpay status.

- High Ability Senior High School Students--The program provides an initial research experience to high school students who excel in their studies.

- Summer Aid Program--This program provides work experience for young students and augments the staff needed to accomplish routine office or laboratory work during the summer months.

- Community Education Program (CEP)--This program is designed to provide female, minority, and handicapped students with-experience and information to facilitate their choices about careers in science. During FY 84, the CEP Program will cooperate with public schools in Montgomery County, Howard County, and the District of Columbia. The program will have the following elements.

a. Speakers Bureau--NBS scientists will make presentations in public schools to junior and senior high school students on scientific topics usually related to the work they do at NBS.

b. Internship--Non-pald internships will be given to high school students to provide them with experience in an NBS laboratory under the supervision of an NBS scientist or engineer.

c. Shadow--Students who have made a preliminary choice to pursue a career in science are given appointments to spend from onehalf to two days with a professional to observe day-to-day scientific activities.

- Support to Black Colleges--NBS' FY 84 Plan for Support to Historically Black Colleges (HBCs) targets ten percent of all expenditures with educational institutions to institutions which have historically black populations. In addition, the following activities have been designed to increase on-going working relationships between NBS managers and HBCs.

a. All requests for research proposals and recruitment announcements for summer, faculty appointments, and postdoctoral appointments will be sent to HBCs.

b. A file describing the technical competencies of HBCs has been developed for use by NBS managers in their grants giving and contracting activities.

c. NBS and the Association for the Advancement of Black Scientists and Engineers will hold a one-week seminar and workshop on the "State-of-the-Art in Analytical Chemistry." The primary 
objective of the workshop will be to provide faculty members and high-potential students from HBCs with theoretical and practical exposure to state-of-the-art instrumental methods for chemical analysis and to establish a rapport between NBS, the participating institutions, faculty members, and students. Over fifty faculty members and students are expected to attend the workshop which will include technical presentations, laboratory techniques, and tours of the facilities.

SECME--The Southeastern Consortium for Minorities in Engineering objectives are to stimulate interest in engineering among minority students of the secondary school level and to assure that these students receive a sound academic foundation in mathematics, science, language arts, and other courses requisite for engineering studies. The consortium consists of representatives from industry, the government, and academia. SECME serves the schools in eight southeastern states with the staff being located at the Georgia Institute of Technology in Atlanta, Georgia.

METCON--The District of Columbia Metropolitan Consortium for Minorities in Engineering primary objective is to increase the number of qualified minority group students in the Washington, DC, metropolitan area interested in engineering. The objective is accomplished through a metropolitan industry and government consortium devoted to making pre-college students aware of career opportunities and challenges in engineering. The consortium also provides the students with enrichment to their educational experience, primarily in mathematics, science, and communication. 
NBS uses a multi-faceted approach to evaluating the results of the program and contributions of its managers. The plan includes the following:

- Annual Review by the NBS Executive Board.

The NBS Director chairs an Annual EEO Program Review at the end of each fiscal year. The objective of the review is to assess progress and shortfalls to the program, discuss plans for the future year's EEO program, and make decisions on program changes, policies, or resources required for the program. The Annual Review is attended by the Executive Board, MOU EEO Coordinators, the Personnel Officer, and EEO Support Division personnel.

- MOU Reviews

The EEO Support Division meets individually with Boulder's management and with each MOU Director and his EEO Coordinator during the first and third quarters. The objective of the meetings is to discuss MOU-specific EEO concerns, review affirmative action progress, and identify EEO problem areas which need to be addressed jointly by the EEO Support Division and the MOU.

- Progress Reports

The EEO Support Division and Personnel Division jointly prepare the EEO report (NBS-1120) at the end of the second quarter and again at the end of the fiscal year. The report includes the following key evaluation criteria:

1. Distribution of employees by sex and ethnic category.

2. Distribution of accessions, separations, awards, and training by sex and ethnic category.

3. Progress toward achievement of hiring and promotion goals.

4. Distribution of the applicant supply by sex and ethnic category.

5. Changes in representation of women and minorities.

Reports are distributed to the Deputy Director and MOU Directors for their use during mid-year and annual performance reviews.

- Annual Report

The EEO Support Division makes an annual written report to the NBS Executive Board. The report describes significant progress, identifies problem areas, and makes recommendations for programmatic changes. 
EEO/affirmative action is an element in the performance agreements of all SES managers. In addition, all Merit Pay managers have also been encouraged to include objectives which included numerical goals for hiring, promoting, and training of women and minorities. They were also asked to identify formal programs and outreach efforts which will be used to increase the quantity of women and minorities in the pipeline for employment.

The performance agreements of SES and Merit Pay managers will be monitored to evaluate the degree to which individual EEO/AAP objectives are being achieved. 
NBS-114A IREV. 2-8C)

\begin{tabular}{|c|c|c|}
\hline U.S. DEPT. OF COMM. & $\begin{array}{l}\text { 1. PUBLICATION OR } \\
\text { REPORT NO. }\end{array}$ & 2. Performlng Organ. Report Nof 3. Publlcation Date \\
\hline $\begin{array}{l}\text { BIBLIOGRAPHIC DATA } \\
\text { SHEET (See Instructions) }\end{array}$ & NBSIR $83-2798$ & December 1983 \\
\hline
\end{tabular}

4. TITLE AND SUBTITLE

Multi-Year Affirmative Action Program for Women and Minorities for Fiscal Years 1982 through 1986

Executive Summary

5. $\operatorname{AUTHOR}(S)$

Linda K. Despeaux

6. PERFORMING ORGANIZATION (If jolnt or other than NBS, see In structions)

NATIONAL BUREAU OF STANDARDS

DEPARTMENT OF COMMERCE

WASHINGTON, D.C. 20234

9. SPONSORING ORGANIZATION NAME AND COMPLETE ADDRESS (Street, Clty, State, ZIP)

7. Contract/Grant No.

8. Type of Report \& Period Covered

Final

National Bureau of Standards

Equal Employment Opportunity Support Division

Washington, DC 20234

10. SUPPLEMENTARY NOTES

Document describes a computer program; SF-185, FIPS Software Summary, is attached.

11. ABSTRACT (A 200-word or less factual summary of most significant information. If document includes a significant bibliography or literature survey, mention it here)

Requirements for the establishment of Federal agency affirmative action programs were first cited by Executive Order 11478 in 1969. Title VII of the Civil Rights Act, as amended in 1972, mandated Federal agencies to maintain affirmative action programs to ensure enforcement of equal employment policy. The NBS multi-year affirmative action program has been designed to assist the Bureau in meeting the goal established by Congress in the Civil Service Reform Act of 1978--i.e., "to provide...a federal workforce reflective of the nation's diversity...."

Women and minorities are underrepresented in scientific occupations at NBS. Although women and minorities are employed in most all administrative, technician, clerical, and blue collar occupations, they are generally underrepresented or absent from higher grades. The affirmative action program has been designed to improve or correct these problems by using three strategies. First, we will expand our outreach efforts with organizations which can impact on the quantity and quality of women and minorities entering occupations in which NBS has staffing requirements. Second, increase the use of internal mechanisms such as training, formal staffing programs, and developmental assignments to move employees into a wider range of occupations and into higher graded positions. And third, we will establish hiring goals which are consistent with labor market participation of women and minorities.

12. KEY WORDS (Six to twelve entries; olphabetical order; capiralize only proper names; and separate key words by semicolons) Affirmative action; Federal Equal Opportunity Recruitment Program; goals; underrepresentation

13. AVAILABILITY

X] Unlimited

For Official Distribution. Do Not Release to NTIS

Order From Superintendent of Documents, U.S. Government Printing Office, Washington, D.C. 20402.

14. NO. OF PRINTED PAGES

27

15. Price

[X] Order From National Technical Information Service (NTIS), Springfield, VA. 2216I

$\$ 8.50$ 

